Article

\title{
Use of Plant Growth Promoting Rhizobacteria in Combination with Chitosan on Maize Crop: Promising Prospects for Sustainable, Environmentally Friendly Agriculture and against Abiotic Stress
}

\author{
Nadège Adoukè Agbodjato ${ }^{1,2}\left(\mathbb{D}\right.$, Toussaint Mikpon ${ }^{2,3}(\mathbb{D}$, , Olubukola Oluranti Babalola $1, *(\mathbb{D}$,

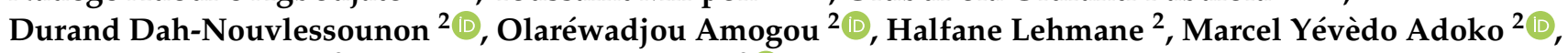 \\ Adolphe Adjanohoun ${ }^{3}$ and Lamine Baba-Moussa ${ }^{2}$
}

1 Food Security and Safety Niche, Faculty of Natural and Agricultural Sciences, North-West University, Private Mail Bag X2046, Mmabatho 2735, South Africa

2 Laboratoire de Biologie et Typage de Moléculaire en Microbiologie (LBTMM), Département de Biochimie et de Biologie Cellulaire, Université d'Abomey-Calavi (UAC), Cotonou 05 BP 1604, Benin

3 Institut National des Recherches Agricoles du Bénin (INRAB), Cotonou 01 BP 284, Benin

* Correspondence: olubukola.babalola@nwu.ac.za; Tel.: +27-(0)1-8389-2568

Citation: Agbodjato, N.A.; Mikpon, T.; Babalola, O.O.; Dah-Nouvlessounon,

D.; Amogou, O.; Lehmane, H.; Adoko,

M.Y.; Adjanohoun, A.; Baba-Moussa, L. Use of Plant Growth Promoting

Rhizobacteria in Combination with

Chitosan on Maize Crop: Promising

Prospects for Sustainable,

Environmentally Friendly

Agriculture and against Abiotic

Stress. Agronomy 2021, 11, 2205.

https://doi.org/10.3390/

agronomy11112205

Academic Editor: Oscar Goñi

Received: 12 September 2021

Accepted: 27 October 2021

Published: 30 October 2021

Publisher's Note: MDPI stays neutral with regard to jurisdictional claims in published maps and institutional affiliations.

Copyright: (c) 2021 by the authors. Licensee MDPI, Basel, Switzerland. This article is an open access article distributed under the terms and conditions of the Creative Commons Attribution (CC BY) license (https:// creativecommons.org/licenses/by/ $4.0 /)$.

\begin{abstract}
Faced with the problems posed by the abusive use of chemical fertilizers and pesticides, it is important to find other alternatives that can guarantee a sustainable and environmentally friendly agriculture. The objective of this study was to evaluate the tolerance of a PGPR (plant growth promoting rhizobacteria) Pseudomonas putida strain to different abiotic stress in in vitro conditions and the synergistic effect of this rhizobacterium in combination with chitosan extracted from crab exoskeletons on the growth of maize in greenhouse conditions. The strain of P. putida was put in culture at different temperatures, $\mathrm{pH}$, and $\mathrm{NaCl}$ concentrations to determine its growth. Then, this strain in combination with chitosan extracts were tested for their ability to improve maize growth for 30 days. The results showed that the P. putida strain showed excellent resistance capacities to different salt concentrations, $\mathrm{pH}$, and temperature variations. Moreover, an improvement in plant growth and biomass yield parameters was observed. The highest values of height, diameter, and leaf area were obtained with the plants treated with the combination of chitosan extracted from Cardisoma armatum and P. putida, with increases of $26.8 \%, 31 \%$, and $55.7 \%$, respectively, compared to the control. This study shows the possibility of using chitosan and rhizobacteria as biostimulants to improve productivity and increase maize yield in a sustainable manner.
\end{abstract}

Keywords: abiotic stress; biostimulants; chitosan; crab exoskeletons; PGPR; sustainable agriculture

\section{Introduction}

Agriculture plays a significant role in the economies of countries around the world. However, it is confronted with many problems leading to substantial crop losses. The constant increase in population, rapid urbanization with the decrease in agricultural land, radical change in climatic conditions, and intensive use of agrochemicals in farming practices that have caused environmental disruptions are confronting humanity with growing problems of food security and agricultural sustainability [1,2]. In addition, the excessive use of chemicals for crop fertilization may lead to the accumulation of minerals and nutrients that cannot be easily utilized for plant consumption, ultimately resulting in soil pollution and toxicity [3].

Consequently, the expansion of crop production relies on increasing soil fertility to ensure food for all under the current global food security scenario [4]. It thus becomes essential to develop different environmentally friendly methods of soil fertility improvement such as the use of natural products and/or organisms in order to reduce the effects 
of harmful organisms and improve agricultural production. Among these products or organisms, we can find plant biostimulants such as chitosan (a chitin derivative extracted from the shells of crustaceans) and soil microorganisms, most especially bacteria whose overall effect promotes plant growth. These bacteria have been grouped under the name of plant growth promoting rhizobacteria (PGPR).

PGPR are bacteria that actively colonize the root rhizosphere and establish free and intimate associations with host plants [5]. They can enhance plant growth and increase plant nutrients through several mechanisms such as siderophore production, antibiotics, and phosphate solubilization [6-9]. Authors in [10] also reported that PGPR could be used as an inexpensive and environmentally friendly approach for enhancing crop growth. Furthermore, microbes have been shown to be of great help in the fight against abiotic stress, via their biological activities at the rhizosphere of plants [11]. The use of PGPR is increasing in agriculture and provides an attractive alternative to chemical fertilizers, pesticides, and food supplements [12].

Concerning chitosan, it is a derivative of chitin. Chitin is the most abundant natural polysaccharide after cellulose, and is obtained by chemical extraction of the exoskeletons of crustaceans, mollusks, and arthropods [13]. Its derivative, chitosan, is thus described as a linear, semicrystalline polysaccharide consisting of glucosamine $\left(\mathrm{C}_{6} \mathrm{H}_{13} \mathrm{NO}_{5}\right)$ and $\mathrm{N}$-acetylglucosamine linked by $\beta(1-4)$ glycosidic bonds, which differs from the chitin polymer by the presence of free amino groups on the second carbon atom of the D-glucose unit, rather than acetamide groups [14]. Chitosan is a biodegradable, antifungal, and non-toxic biopolymer with antimicrobial and plant immunity-triggering properties [15-17]. Several works refer to the stimulating effect of chitosan on plant growth and development in cucumber [18], strawberry [19], tomato, eggplant [20], radish [21], cowpea [22], and common bean [23]. Authors in [24] also reported that chitosan improves morpho-physiological parameters and attenuates the detrimental effect of abiotic stresses stimulation of stress transduction pathways. The use of these two bioproducts would be interesting to improve growth and also control pathogenic diseases. To this effect, ref. [25] in their research work, showed that the application of Pseudomonas sp. in combination with chitosan reduced the severity of disease caused by tomato leaf curl virus (ToLCV) by up to $90.33 \%$ in field conditions.

Based on this evidence, the use of low-input agriculture through the use of these organic sources is, therefore, becoming a necessity to achieve profitable and sustainable agriculture. It is then necessary for agricultural research to position itself in the development of processes to make chitosan-based bioproducts and beneficial microorganisms available to producers in the agricultural sector in order to improve agricultural productivity. It is in this context that this work aimed to evaluate, on the one hand, the tolerance of a PGPR Pseudomonas putida strain to different abiotic stresses under in vitro conditions and, on the other hand, the synergistic effect of this rhizobacterium in combination with chitosan extracted from the exoskeletons of local Benin crabs (Callinectes amnicola and Cardisoma armatum) on the growth of greenhouse maize in Benin.

\section{Materials and Methods}

\subsection{Material}

The maize seed used was of the variety EVDT 97 STR W and came from the Centre de Recherches Agricoles du Sud (CRA-Sud) of the Institut National des Recherches Agricoles du Bénin. This variety shows good resistance to American rust, streak, helminthosporiosis, curvulariasis, and drought [26]. 
The chitosans used were chitin derivatives extracted from the exoskeletons of crabs (Callinectes amnicola and Cardisoma armatum) collected in Benin according to the method adapted by [27]. The extracts obtained were stored at the Laboratoire de Biologie et de Typage Moléculaire en Microbioogie (LBTMM). They are solid bioproducts containing natural polymers, biodegradable, and non-toxic for animals and plants.

The PGPR rhizobacterium named Pseudomonas putida was used in this study to evaluate the synergistic effect of PGPR in combination with extracted chitosans. This strain stored at $-85^{\circ} \mathrm{C}$ in Mueller Hinton nutrient broth with addition of glycerol $(10 \%)$ in the laboratory was isolated and identified by [28] and characterized by [7] for its PGPR profile.

\subsection{In Vitro Evaluation of the Ability of P. putida to Grow under Different Environmental Stress} Conditions (Temperature, $p H$, Salt)

\subsubsection{Evaluation of the Effects of Temperature Variation on the Growth of P. putida}

The ability of $P$. putida to grow under different temperatures $(4,16,25,30,37,40,44$, 48 , and $50{ }^{\circ} \mathrm{C}$ ) was performed by the method adapted by [29] on Mueller Hinton (MH) liquid nutrient broth inoculated with $100 \mu \mathrm{L}$ of the bacterial culture of the tested strain for $48 \mathrm{~h}$ under agitation. The growth of P. putida was evaluated by reading the optical density (OD) with a spectrophotometer (BioMATE 3S, Thermo scientific, Waltham, MA, USA) at the wavelength of $600 \mathrm{~nm}$ and the experiments were performed in three r replicates. [29].

\subsubsection{Evaluation of the Effects of $\mathrm{pH}$ Variation on the Growth of P. putida}

The effect of $\mathrm{pH}$ was evaluated by the method adapted by [29] on Mueller Hinton $(\mathrm{MH})$ liquid nutrient medium. The medium was adjusted to different $\mathrm{pH}$ values, 4, 5, 6, 7, $8,9,10$, and 12 , to evaluate the ability of the strain to grow over a wide range of $\mathrm{pH}$ values. The growth of the strain was evaluated by measuring the optical density of the cultures with a spectrophotometer (BioMATE 3S, Thermo scientific) at the wavelength of $600 \mathrm{~nm}$ and the experiments were carried out in three replicates.

2.2.3. Evaluation of the Effects of Different Salt Concentrations $(\mathrm{NaCl})$ on the Growth of P. putida

Salt tolerance of P. putida was evaluated by the method adapted by [29] on Mueller Hinton (MH) liquid nutrient broth inoculated with $100 \mu \mathrm{L}$ of one culture of each rhizobacterium and incubated at $30{ }^{\circ} \mathrm{C}$ for $48 \mathrm{~h}$ under agitation in the presence of the following increasing concentrations of $\mathrm{NaCl}: 0,0.2,0.4,0.6,0.8$, and $1 \mathrm{M}$. The optical density of each culture was read with a spectrophotometer (BioMATE 3S, Thermo scientific) at the wavelength of $600 \mathrm{~nm}$ and the experiments were performed in three replicates.

2.3. Evaluation of the Effects of Chitosans Produced in Benin from C. amnicola and C. armatum in Combination with P. putida on the Greenhouse Growth of Maize on Ferrallitic Soil

2.3.1. Extraction of Chitosans from Exoskeletons of C. armatum and C. amnicola

- The samples of land crab (Cardisoma armatum) and freshwater crab (Callinectes amnicola) used were collected from anglers and crab sellers, respectively, in the municipalities of Ajohoun and Abomey-Calavi in Benin. After the crab samples were collected, the shells were separated from the meat. These shells were washed with tap water then with distilled water before being dried. The shells were sprayed with acetone and placed in an oven at $50{ }^{\circ} \mathrm{C}$ for $24 \mathrm{~h}$ to activate the drying process. Drying was continued in a pasteurized oven at $50{ }^{\circ} \mathrm{C}$ for 10 days. After drying, all samples were ground and powdered using a Retsch mill type SM 2000/1430/Upm/Smfet [27].

- The powders of the two crab species obtained were used to obtain chitosan in four steps according to the method of [30] adapted by [27], which consists of a demineralization of the powder in acid medium, followed by a deproteinization of the powder in basic medium, then a bleaching of the powder, and finally a deacetylation of the powder by hydrothermochemical process in basic medium. 


\subsubsection{Refreshing of the Strain and Preparation of P. putida Suspensions}

The P. putida strain previously stored at $-85^{\circ} \mathrm{C}$ was revivified by subculturing on King B agar medium at $30^{\circ} \mathrm{C}$ for $24 \mathrm{~h}$ at $30^{\circ} \mathrm{C}$. After $24 \mathrm{~h}$, bacterial inocula were obtained by culture in a nutrient medium liquid (Mueller Hinton broth) for $24 \mathrm{~h}$ at $30^{\circ} \mathrm{C}$. Then, another culture was carried out from the previous $24 \mathrm{~h}$ at the appropriate temperatures. After the $24 \mathrm{~h}$ incubation, the cultures were then adjusted to a microbial concentration of about $1 \times 10^{8} \mathrm{CFU} / \mathrm{mL}$ (OD 0.45 at $610 \mathrm{~nm}$ ) with a spectrophotometer (BioMATE 3S, Thermo scientific) according to the method described by [31].

\subsubsection{Experimental Device}

The experimental design used was a randomized block of six treatments with three replicates. The treatments were defined as follows:

- $\quad$ T1: CTL = Uncoated seed (without chitosan and P. putida) (control);

- $\quad$ T2: Cali = Seeds coated with chitosan extracted from C. amnicola;

- $\quad$ T3: Card = Seeds coated with chitosan extracted from C. armatum;

- $\quad$ T4: Puti = Seeds inoculated with Pseudomonas putida;

- $\quad$ T5: Cali + puti $=$ Seeds coated with the combination of $C$. amnicola + Pseudomonas putida;

- $\quad$ T6: Card + puti $=$ Seeds coated with the combination of C. armatum + Pseudomonas putida.

\subsubsection{Filling the Pots}

The substrate used was an undegraded ferrallitic-type soil sampled at a depth of 0 to $20 \mathrm{~cm}$ using a marked shovel spade. This substrate was collected at the experimental station of the Centre de Recherches Agricoles-Sud du Bénin and dried in the sun. It was then sieved and double sterilized at $120^{\circ} \mathrm{C}$ for 20 minutes at an interval of $24 \mathrm{~h}$ [32]. Six kilograms of the substrate were weighed and poured into each pot, previously labeled. Each pot was moistened to 2/9th of the Maximum Retention Capacity (MRC) of the substrate water $24 \mathrm{~h}$ before sowing [33].

\subsubsection{Coating of Seeds with Extracted Chitosans Based on C. amnicola and C. armatum}

The coating of the seeds by the chitosans was done on the eve of sowing. Clay was used as a binder to coat the seeds. The amount of chitosan and clay used applied was $10 \%$ of the weight of the maize seeds. An amount of water equivalent to $1200 \mathrm{~mL} / \mathrm{kg}$ of the product was added to obtain the mixture. The seeds were coated in each mixture, thus obtained according to the type of chitosan. They were then air-dried according to the recommendations of [34].

\subsubsection{Sowing of Coated Seeds, Inoculation, and Maintenance of Pots}

After placing the pots in the greenhouse, two maize seeds previously coated with each chitosan according to the defined treatments were sown after opening the pots about $5 \mathrm{~cm}$ deep in the center of each pot. Then, they were immediately inoculated with $10 \mathrm{~mL}$ of the P. putida bacterial suspension with a concentration of about $1 \times 10^{8} \mathrm{CFU} / \mathrm{mL}$ according to each treatment, and the pots were immediately closed again.

The pots were watered at 2/9th of their Maximum Water Retention Capacity every $48 \mathrm{~h}$ for 30 days. After one week, the plant was de-wedded to one plant per pot. The average temperature values inside the shelter were determined using a thermometer. To obtain the average temperature values inside the greenhouse, a thermometer was used. The average daytime temperature was $35.85^{\circ} \mathrm{C}$ and the average night-time temperature was $37.5^{\circ} \mathrm{C}$ during the test period. 


\subsubsection{Chemical Analysis of Soil Used in Greenhouses}

The chemical analysis of part of the soil $(500 \mathrm{~g})$ used was carried out at the Laboratoire des Sciences du Sol, Eau et Environment (LSSEE) of the Institute National de Recherches Agricoles du Bénin (INRAB). The analyses carried out consisted of $\mathrm{pH}$ measurement using an electrode $\mathrm{pH}$ meter in a soil/water ratio of $2 / 5(\mathrm{~g} / \mathrm{mL})$, determination of organic matter [35], determination of assimilable phosphorus using the Bray-1 method [36], and of exchangeable bases $(\mathrm{Ca}, \mathrm{Mg}, \mathrm{K}$, and $\mathrm{Na})$ by the method of [37].

\subsubsection{Collection of Growth and Yield Parameters}

Plant growth parameters were assessed by collecting height and crown diameter data on each maize plant at the time of de-mating and every $96 \mathrm{~h}$, i.e., on the 7th, 11th, 15th, 19th, 23rd, 27th, and 30th day after seeding (DAS), while data on leaf length and width were collected on the 30th DAS for leaf area determination. The height of a maize plant is the distance from the crown to the last ligule. It was measured with a tape measure. The diameter at the plant crown was measured using the calliper at the plant crown. The ligulate leaves' surface area was estimated by multiplying the length and width of the leaves by 0.75 [38]. It involved the last two ligulate leaves of each plant. This measurement was carried out only at the 30th DAS. The collected data were recorded in a register. Furthermore, the aerial parts of the plants were cut off, the roots were separated from the culture substrate, and the fresh biomasses were weighed. The dry matter (above and below ground) was determined by weighing after drying in an oven at $70{ }^{\circ} \mathrm{C}$ for $72 \mathrm{~h}$.

\subsubsection{Statistical Analysis of the Data}

Linear mixed-effect models on longitudinal data (using nlme packages for model fitting and lsmeans packages for the calculation of fitted means) were fitted to evaluate the effects of chitosan-based treatments and its combination with P. putida on the growth parameters (height and crown diameter) of maize plants. These effects are graphically represented by the evolution curves per treatment and days after sowing (DAS).

As for the statistical analysis of maize plant yield performance following the different chitosan treatments, a one-factor analysis of variance was performed by yield parameters using the "car" package in the R 4.0.2 software (R Core Team, 2020). This analysis of variance was followed by a post hoc test of pairwise comparisons using Tukey post hoc test [39] was carried out to assess the statistical differences of the means using u multcomp packages. The descriptive statistics calculated required the use of the dplyr and DescTools packages. The packages ggplot 2 and ggpur were used to represent the results graphically. A probability $(p$-value $)<0.05$ is considered significant.

A correlation matrix was established in order to assess the dependency between the different parameters measured. The Pearson method was used and using the package corrplot, the coefficients were visualized.

\section{Results}

\subsection{In Vitro Effect of P. putida Tolerance to Different Environmental Stress Conditions}

\subsubsection{Effect of Temperature Variation on the Growth of P. putida}

The growth of $P$. putida was observed at the different temperatures tested. It was optimal at $30{ }^{\circ} \mathrm{C}$ (with an optical density equal to 1.51 ) but reduced at $40{ }^{\circ} \mathrm{C}$ (with an optical density equal to 1.01). At extreme temperatures $\left(4 ; 16 ; 48\right.$ and $\left.50{ }^{\circ} \mathrm{C}\right)$, P. putida maintained an appreciable but low growth rate (Figure 1a). 
(a)

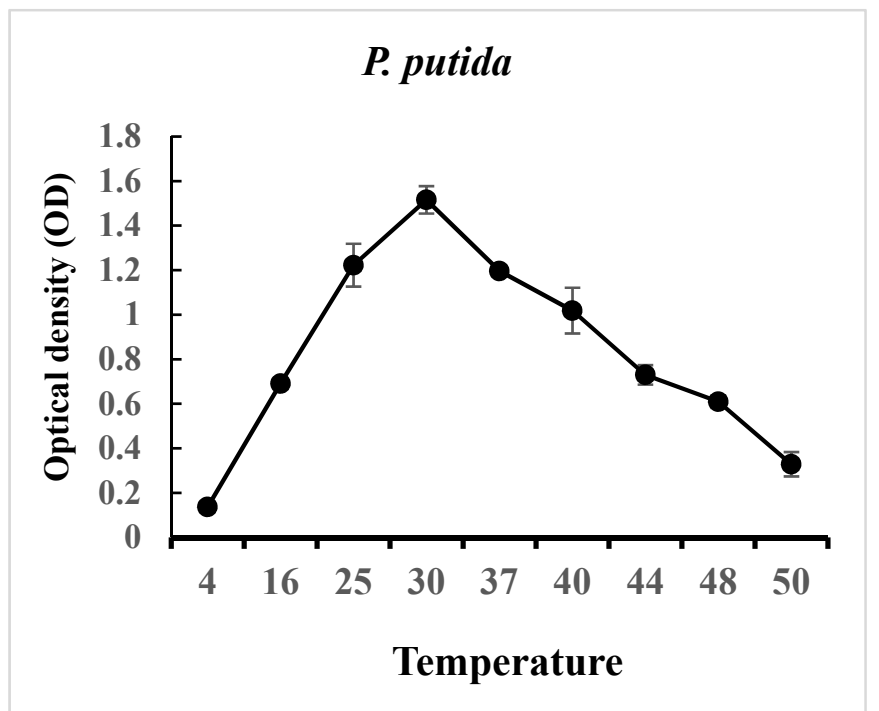

(b)

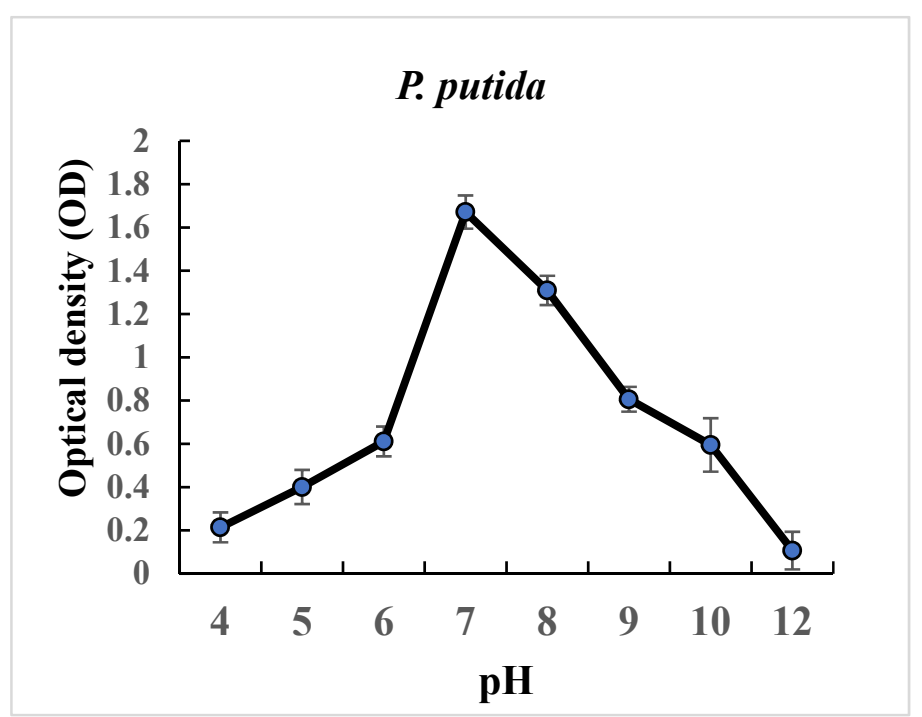

(c)

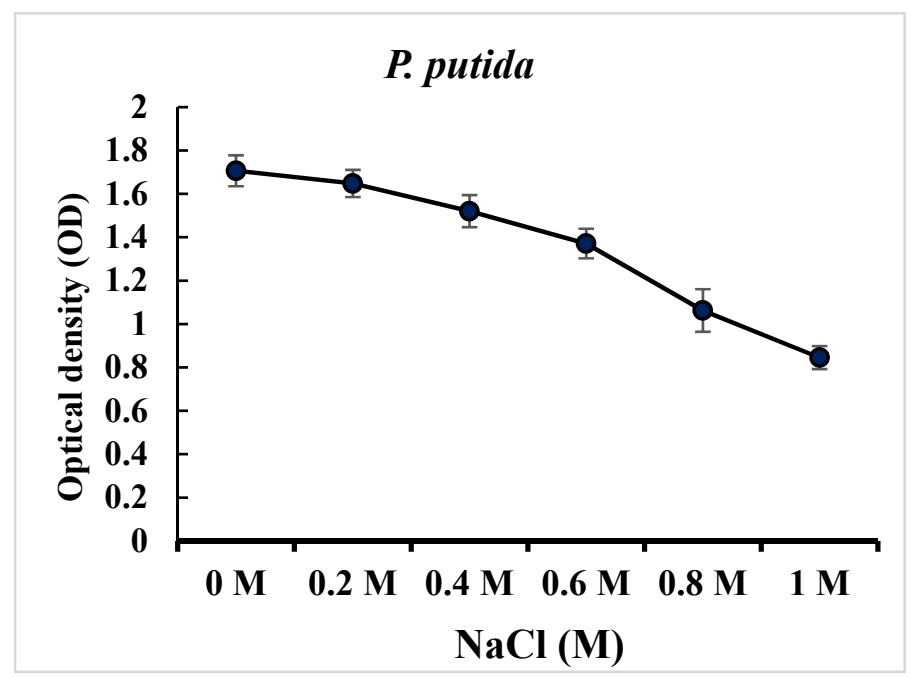

Figure 1. (a-c): Effect of temperature, $\mathrm{pH}$, and $\mathrm{NaCl}$ on the growth of P. putida.

\subsubsection{Effect of $\mathrm{pH}$ Variation on the Growth of P. putida}

Regarding $\mathrm{pH}$ tolerance, $P$. putida grew in a wide range of $\mathrm{pH}$ from 4 to 8 . At neutrality $(\mathrm{pH}=7)$, P. putida reached its optimal growth with an OD equal to 1.61. On the other hand, inhibition of strain growth was visible from $\mathrm{pH} 9(\mathrm{OD}=0.81)$ until the decline at $\mathrm{pH} 12$ $(\mathrm{OD}=0.12)$. (Figure $1 \mathrm{~b})$.

\subsubsection{Effect of Salt $(\mathrm{NaCl})$ at Different Concentrations on the Growth of P. putida}

The growth of $P$. putida on nutrient broth was evaluated by measuring the turbidity of the culture at $\mathrm{NaCl}$ concentrations ranging from 0 to $1 \mathrm{M}$. A good tolerance capacity of P. putida to $\mathrm{NaCl}$ was noted with a concentration ranging from $0.2 \mathrm{M}$ to $1 \mathrm{M}$. The P. putida strain subjected to $\mathrm{NaCl}$ concentration ranging from 0 to $0.4 \mathrm{M}$ revealed good salt tolerance ability with OD ranging from 1.71 to 1.52 . The P. putida strain maintained an appreciable growth rate at the concentration between $0.6 \mathrm{M}$ and $0.8 \mathrm{M}$ and dropped as the amount of $\mathrm{NaCl}$ increased (1 M) (Figure 1c). 


\subsection{Chemical Characteristics of the Soil}

Table 1 shows the chemical characteristics of the soil used. This substrate is moderately acidic, with a very low percentage of organic matter $(1.15 \%)$ and organic carbon $(0.63 \%)$. The content of assimilable phosphorus ( $8 \mathrm{ppm}$ ) is very low and the sum of exchangeable bases of about $4 \mathrm{meq} / 100 \mathrm{~g}$.

Table 1. Chemical characteristics of the used soil for maize grow.

\begin{tabular}{cccccccccc}
\hline & \multicolumn{2}{c}{$\mathrm{pH}$} & \multicolumn{1}{c}{ PA (ppm) } & OC (\%) & OM (\%) & \multicolumn{4}{c}{ EB (meq/100 g) } \\
\cline { 2 - 10 } Sample & Water & KCl & & & & Ca & Mg & K & Na \\
\hline Soil & 5.3 & 4.7 & 8 & 0.63 & 1.15 & 2.63 & 0.61 & 0.13 & 0.22
\end{tabular}

PA: phosphorus assimilable, OC: organic carbon, OM: organic matter, EB: exchangeable bases; ppm: parts per
million; meq: milliequivalents.

\subsection{Effects of Chitosan-Based Treatments and Its Combination with P. putida on the Growth Parameters of Maize Plants}

The use of chitosan-based bioproducts and PGPR is one of the alternative solutions to increase crop productivity and plant health. The results presented in Table 2 show an improvement in growth parameters at day 30 after sowing following the use of chitosans extracted from C. amnicola and C. armatum and their combination with P. putida on maize growth (Table 2). Moreover, the results show a significant difference between maize plant heights, crown diameters, and leaf areas according to the treatments applied (Figures 2-4).

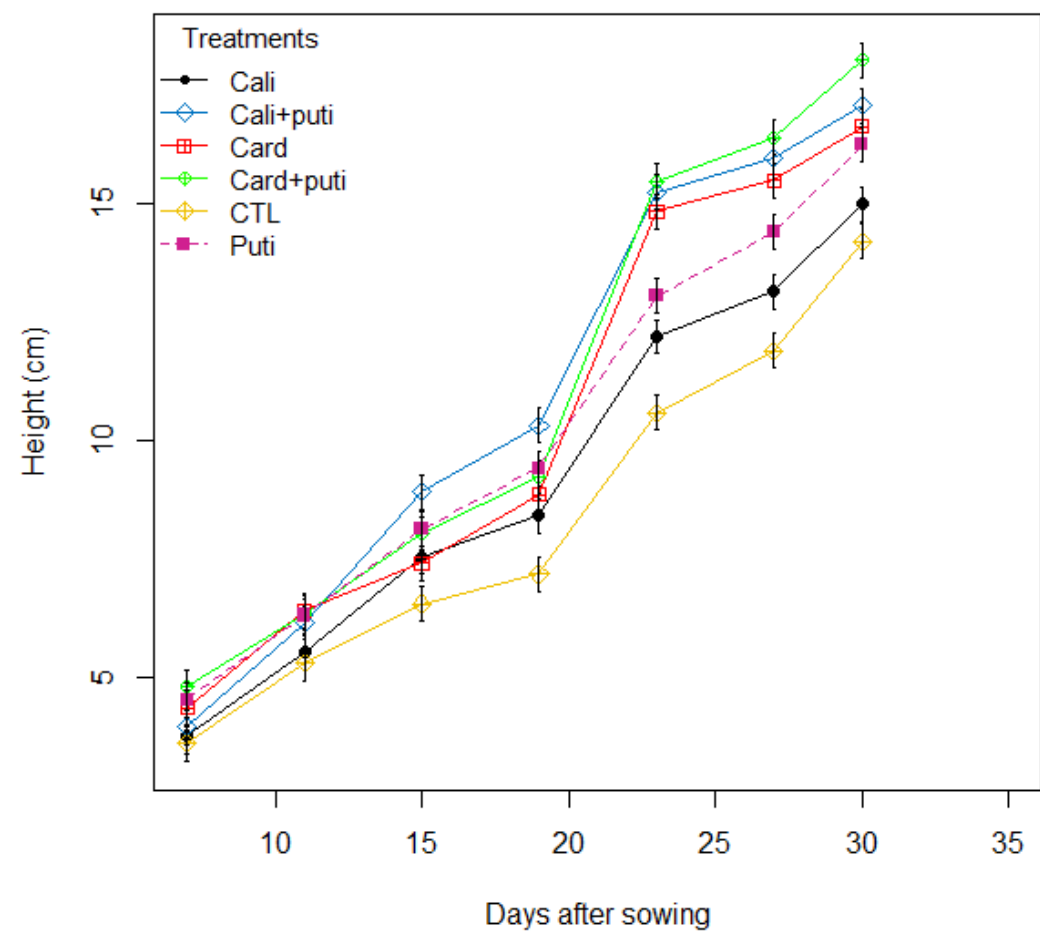

Figure 2. Plant height development as a function of treatments and overtime. CTL $=$ Control (Uncoated seed (without chitosan and P. putida); Cali = Seeds coated with chitosan extracted from Callinectes amnicola; Card = Seeds coated with chitosan extracted from Cardisoma armatum; Puti $=$ Seeds inoculated with Pseudomonas putida; Cali + puti $=$ Seeds coated with the combination of Callinectes amnicola + Pseudomonas putida; Card + puti $=$ Seeds coated with the combination of Cardisoma armatum + Pseudomonas putida. 


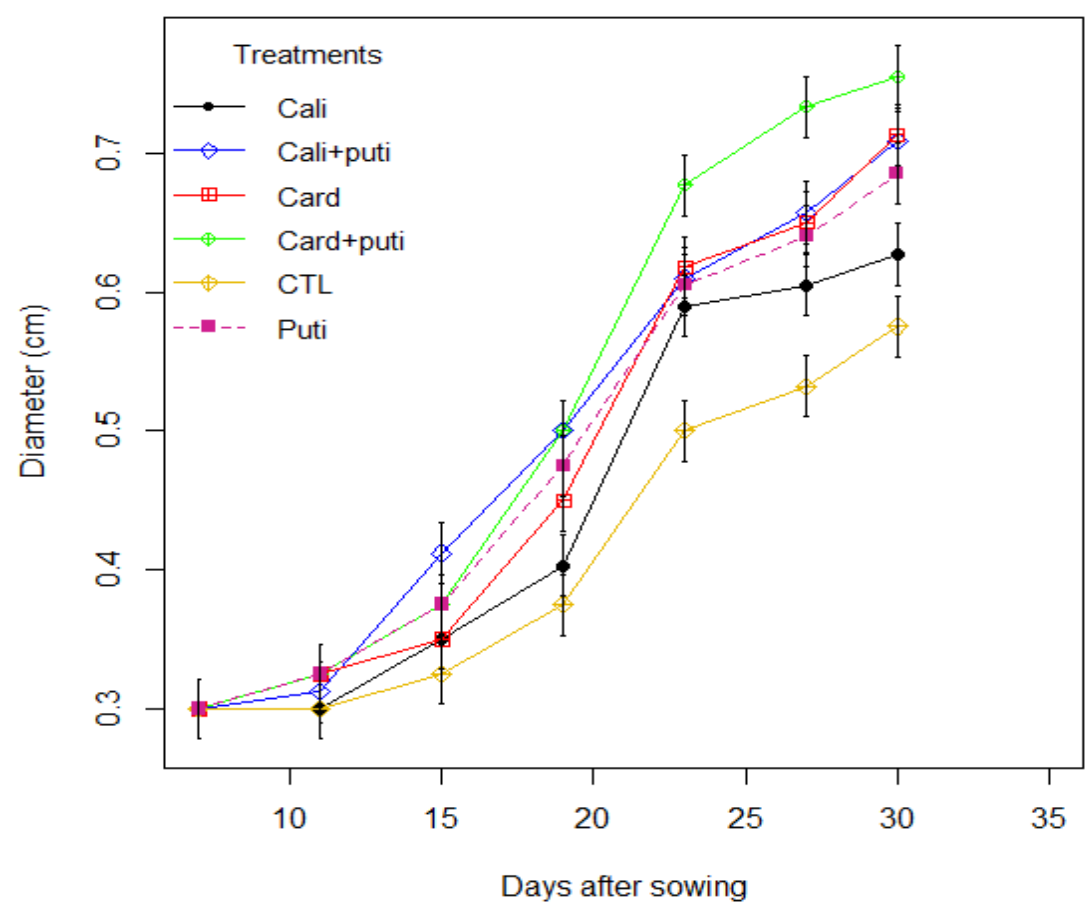

Figure 3. Plant diameter development as a function of treatments and over time. CTL $=$ Control (Uncoated seed (without chitosan and P. putida); Cali = Seeds coated with chitosan extracted from Callinectes amnicola Card $=$ Seeds coated with chitosan extracted from Cardisoma armatum; Puti = Seeds inoculated with Pseudomonas putida; Cali + puti $=$ Seeds coated with the combination of Callinectes amnicola + Pseudomonas putida; Card + puti $=$ Seeds coated with the combination of Cardisoma armatum + Pseudomonas putida.

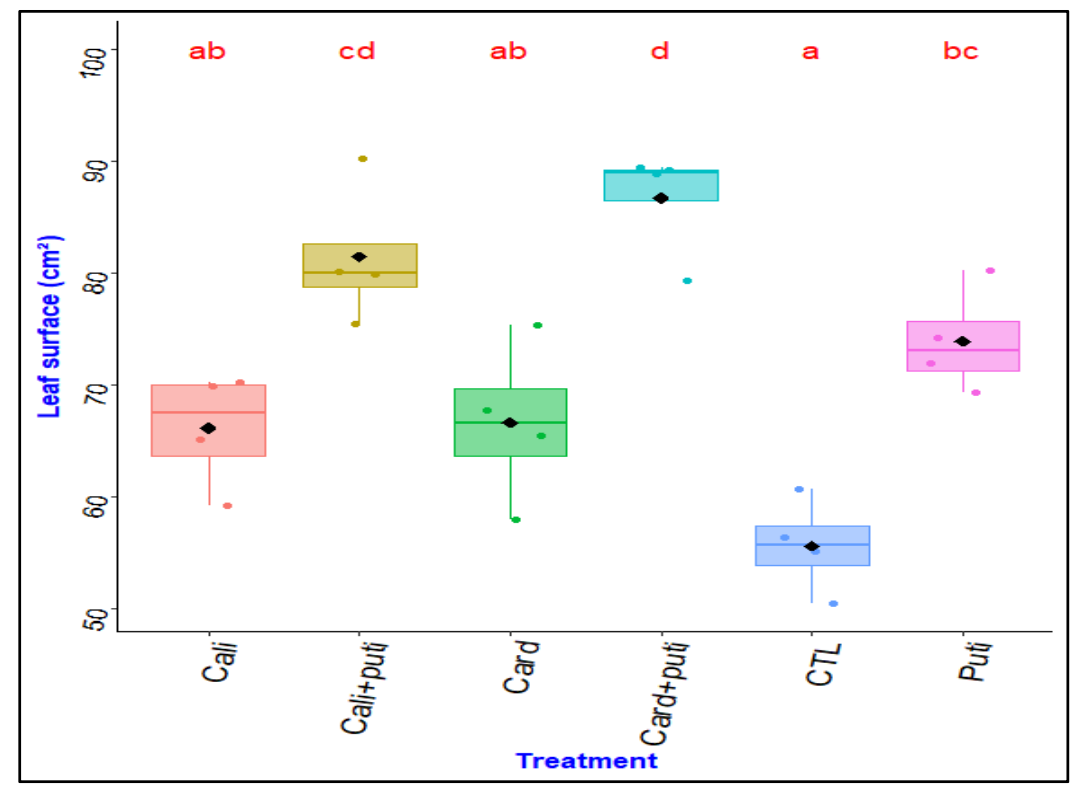

Figure 4. Effects of treatments on the foliar surface of plants. ${ }^{a}$ ab, b, bc, etc.: represent the results of the tests of comparison of means after the results of analysis of variance. CTL $=$ Control (Uncoated seed (without chitosan and P. putida); Cali = Seeds coated with chitosan extracted from Callinectes amnicola; Card $=$ Seeds coated with chitosan extracted from Cardisoma armatum; Puti $=$ Seeds inoculated with Pseudomonas putida; Cali + puti $=$ Seeds coated with the combination of Callinectes amnicola + Pseudomonas putida; Card + puti $=$ Seeds coated with the combination of Cardisoma armatum + Pseudomonas putida. 
Table 2. Mean value ( \pm standard error) of the effect of chitosans produced in combination with P. putida on maize plant growth parameters.

\begin{tabular}{|c|c|c|c|c|c|c|c|}
\hline \multirow{2}{*}{ Observed Data } & \multicolumn{6}{|c|}{ Treatments } & \multirow[b]{2}{*}{$p$-Value } \\
\hline & CTL & Cali & Card & Puti & Cali + puti & Card + puti & \\
\hline Height (cm) & $14.2^{\mathrm{a}} \pm 0.12$ & $15.0^{\mathrm{ab}} \pm 0.03$ & $16.6^{b c} \pm 0.23$ & $16.2^{b c} \pm 0.58$ & $17.0^{\mathrm{c}} \pm 0.51$ & $18 \pm 0.71$ & $0.0001^{* * *}$ \\
\hline Diameter $(\mathrm{cm})$ & $0.58^{\mathrm{a}} \pm 0.03$ & $0.63^{\mathrm{ab}} \pm 0.02$ & $0.71^{b c} \pm 0.04$ & $0.69^{b c} \pm 0.03$ & $0.71^{c} \pm 0.01$ & $0.76 \pm 0.03$ & $0.0006^{* * *}$ \\
\hline Leaf Area $\left(\mathrm{cm}^{2}\right)$ & $55.7^{\mathrm{a}} \pm 2.09$ & $66.1^{\mathrm{ab}} \pm 2.57$ & $66.7^{\mathrm{ab}} \pm 3.58$ & $73.9^{b c} \pm 2.32$ & $81.4^{\mathrm{cd}} \pm 3.10$ & $86.7 \pm 2.44$ & $2.8 \times 10^{-6 * * *}$ \\
\hline
\end{tabular}

***: indicates a very significant probability at the $5 \%$ threshold. a, ab, b, bc, etc.: represent the structuring of the averages after the post. CTL = Control (Uncoated seed (without chitosan and P. putida); Cali = Seeds coated with chitosan extracted from Callinectes amnicola; Card $=$ Seeds coated with chitosan extracted from Cardisoma armatum; Puti $=$ Seeds inoculated with Pseudomonas putida $;$ Cali + puti $=$ Seeds coated with the combination of Callinectes amnicola + Pseudomonas putida; Card + puti = Seeds coated with the combination of Cardisoma armatum + Pseudomonas putida.

\subsubsection{Height}

Figure 2 shows the evolutionary trend of maize plants as a function of treatments over time. Good plant width development from emergence until 30 DAS. The results of the linear mixed-effects model showed that the development in plant diameter depends on the treatments but also varies with time $(p$-value $<0.001)$. The height of all the plants evolved as a function of time but from 11 DAS to 30 DAS, there was a clear difference in the evolution of the height of treated and untreated plants. Indeed, from the 7 th to the 10th, the plants' height knew a similar evolution, but from the 11th to the 30th of DAS, we noted a clear difference in the development of the plants according to each treatment. Thus, the plants treated with the combination of chitosan extracted from C. armatum and P. putida were clearly more important than the other treatments. The average heights measured on the 30th day after sowing varied between $14.2 \pm 0.12 \mathrm{~cm}$ and $18 \pm 0.71 \mathrm{~cm}$ (Table 2). The lowest values were recorded by control plants while the highest values were recorded by plants treated with the combination of chitosan extracted from C. armatum and P. putida. The treatment based on chitosan extracted from C. armatum alone resulted in a $17 \%$ increase in plant height compared to the control. In comparison, its combination with $P$. putida resulted in a $26.8 \%$ improvement in plant performance compared to the control. The same observations were made with the treatment under chitosan extracted from C. amnicola slightly induced an increase of $6 \%$. Furthermore, when combined with P. putida, the increase was $20 \%$ compared to the control (Table 2).

\subsubsection{Diameter}

Figure 3 shows the width development of the plants from emergence until 30 DAS. The results of the linear mixed-effects model show that the development in plant diameter depended on the treatments but also varied as a function of time ( $p$-value $<0.001)$.

In fact, between the 7th and 20th day, plants treated with the combination of chitosan extracted from C. amnicola and P. putida had the best development in diameter, followed by plants treated with the combination of chitosan extracted from C. armatum and P. putida and plants treated with P. putida only which had the same development (Figure 3). After the 20th day, the development of the plants treated with chitosan extracted from C. armatum and P. putida was significantly higher than the other treatments. The evolution of the plants under the combination of chitosan extracted from C. amnicola and P. putida and chitosan extracted from C. armatum and P. putida was similar (Figure 3). The mean diameters measured on the 30th day after sowing varied between $0.58 \pm 0.03 \mathrm{~cm}$ and $0.76 \pm 0.03 \mathrm{~cm}$ (Table 1). The control plants were those with the low development in diameter. At the same time, those treated with the combination of chitosan extracted from C. armatum and P. putida induced the high development in diameter. In fact, the treatment based on chitosan extracted from C. armatum alone ensured an increase of $24 \%$ compared to the control. In comparison, its combination with P. putida induced an improvement in plant performance of $31 \%$ compared to the control plants. The combination of chitosan extracted from C. amnicola and P. putida induced an increase of $23 \%$ compared to the control. On the 
other hand, plants treated only with P. putida resulted in a $20 \%$ increase compared to the control plants (Table 2).

\subsubsection{Leaf Area}

In terms of leaf area, combinations between chitosans and P. putida gave the best development (Figure 4). In addition, the plants treated with the combination of chitosan extracted from C. armatum and P. putida provided the best leaf development at the end of the greenhouse trials (30th day after sowing), and the average value of the leaf area of these plants was $86.7 \pm 2.44 \mathrm{~cm}^{2}$, an increase of more than $55 \%$ of the leaf area of the plants compared to the control plants. The plants treated with chitosan extracted from C. amnicola in combination with P. putida were the second most important with an average of $81.4 \pm 3.10 \mathrm{~cm}^{2}$ and ensured an increase of about $46 \%$. Treatments based solely on chitosan or P. putida gave intermediate results, however, clearly superior to the control treatment. However, it should be noted that the plants treated with P. putida showed a greater development than those treated with chitosan. Thus, treatments with P. putida, chitosan extracted from C. armatum, and chitosan extracted from C. amnicola induced, respectively, an increase in leaf area of 32\%, 19\%, and 18\% (Table 2).

3.3.4. Effects of Chitosan-Based Treatments and Its Combination with P. putida on Maize Plant Yield Parameters

Table 3 shows the average biomass obtained from maize plants per treatment. The results indicate that the effect of the different treatments on the performance of the maize plants was significant regardless of the type of biomass measured.

Table 3. Mean value ( \pm standard error) of the effect of chitosans produced in combination with $P$. putida on the biomass yield parameters of maize plants.

\begin{tabular}{|c|c|c|c|c|c|c|c|}
\hline \multirow{2}{*}{ Observed Data } & \multicolumn{7}{|c|}{ Treatments } \\
\hline & CTL & Cali & Card & Puti & Cali + puti & Card + puti & $p$-Value \\
\hline FAB $(g)$ & $8.48^{a} \pm 0.6$ & $9.99^{a} \pm 0.6$ & $13^{b} \pm 0.76$ & $14.3^{b c} \pm 0.56$ & $13.3^{b} \pm 0.42$ & $16.7^{c} \pm 0.47$ & $1.1 \times 10^{-7} * * *$ \\
\hline $\mathrm{DAB}(\mathrm{g})$ & $1.03^{\mathrm{a}} \pm 0.04$ & $1.21^{\mathrm{a}} \pm 0.07$ & $1.83 \mathrm{~b} \pm 0.03$ & $1.94^{b} \pm 0.07$ & $1.82^{b} \pm 0.07$ & $2.33^{c} \pm 0.15$ & $7.5 \times 10^{-9 * * *}$ \\
\hline FUB (g) & $3.75^{a} \pm 0.38$ & $5.28^{\mathrm{ab}} \pm 0.56$ & $7.72^{c} \pm 0.30$ & $7.85^{c} \pm 0.18$ & $6.52^{b c} \pm 0.22$ & $7.92^{c} \pm 0.27$ & $2.0 \times 10^{-7 * * *}$ \\
\hline DUB $(g)$ & $0.66^{\mathrm{a}} \pm 0.09$ & $1.04^{\mathrm{ab}} \pm 0.05$ & $1.56^{b c} \pm 0.12$ & $1.74^{c} \pm 0.10$ & $1.54^{b c} \pm 0.14$ & $1.84^{\mathrm{c}} \pm 0.2$ & $1.6 \times 10^{-5 * * *}$ \\
\hline
\end{tabular}

***: indicates a very significant probability at the $5 \%$ threshold. ${ }^{a}$, ab, b, bc, etc.: represent the structuring of the averages after the post hoc Tukey test. CTL $=$ Control (Uncoated seed (without chitosan and P. putida); Cali = Seeds coated with chitosan extracted from Callinectes amnicola ; Card $=$ Seeds coated with chitosan extracted from Cardisoma armatum; Puti = Seeds inoculated with Pseudomonas putida; Cali + puti $=$ Seeds coated with the combination of Callinectes amnicola + Pseudomonas putida; Card + puti $=$ Seeds coated with the combination of Cardisoma armatum + Pseudomonas putida.; FAB: fresh aerial biomass; DAB: dry aerial biomass; FUB: fresh underground biomass; DUB: dry underground biomass.

In fact, an increase of between $18 \%$ and $97 \%$ in the fresh aerial biomass of the treated plants was observed compared to the control plants. The average fresh aerial biomass (FAB) observed was respectively $16.7 \mathrm{~g}, 14.3 \mathrm{~g}, 13.3 \mathrm{~g}, 13 \mathrm{~g}$, and $9.99 \mathrm{~g}$ for plants treated with chitosan extracted from C. armatum and P. putida, plants treated with P. putida, plants subjected to chitosan extracted from C. amnicola and P. putida, plants subjected to chitosan extracted from C. armatum, and chitosan extracted from C. amnicola.

Statistically, the combination of chitosan extracted from C. armatum and P. putida gave very different results from the other treatments (Table 3). Chitosan extracted from C. armatum and the combination chitosan extracted from C. amnicola and P. putida gave similar results while chitosan extracted from $C$. amnicola gave similar results to the control. The same trends observed in the fresh aerial biomass (FAB) were observed in the dry above-ground biomass (Table 3 ).

The effect of the treatments on the fresh underground biomass (FUB) was greater compared to the results for the fresh above-ground biomass. An increase of between $40 \%$ and $110 \%$ compared to the control was induced depending on the treatment. Thus, the fresh underground biomass (FUB) was $7.92 \mathrm{~g}$ for the combination of chitosan extracted from C. armatum and P. putida; $7.85 \mathrm{~g}$ for P. putida; $7.72 \mathrm{~g}$ for chitosan extracted from C. armatum; 
$6.52 \mathrm{~g}$ for combination of chitosan extracted from C. amnicola and P. putida; and $5.28 \mathrm{~g}$ for chitosan extracted from $C$. amnicola. The effects induced by these treatments were significant with four groups. Indeed, the treatments C. armatum and P. putida, P. putida, and chitosan extracted from $C$. armatum formed the first group with similar effects then came groups 2 and 3 constituted, respectively, by the combined treatment of chitosan extracted from C. amnicola and P. putida and chitosan extracted from C. amnicola which give intermediate results relative to the last group constituted by the control (Table 3).

For dry subsurface biomass (Table 3), the results were also broadly similar to the results obtained for fresh subsurface biomass. However, while for the fresh subsurface biomass, the chitosan treatment extracted from C. armatum was in the first group, for the dry subsurface biomass, these effects were similar to those of group 2 (chitosan extracted from C. amnicola and P. putida).

\subsubsection{Correlation of the Various Parameters}

The measured linear dependence between the growth parameters (height, diameter, and leaf area) and yield (fresh and dry aerial biomass, fresh and dry underground biomass) of the plants is presented in Figure 5. All correlations were positive and important as shown by the size of the circles and the intensity of the colors (rcorr > 0.70). A linear relationship between growth and yield parameters can be deduced from this, the most important of which is the relationship between plant height and diameter ( $($ corr $=0.99)$ then the relationship between fresh aerial biomass $(\mathrm{FAB})$ and diameter/height ( $\mathrm{rcorr}=0.95)$. The relationship between leaf area and fresh underground biomass (FUB) is the least important $($ rcorr $=0.72)$.

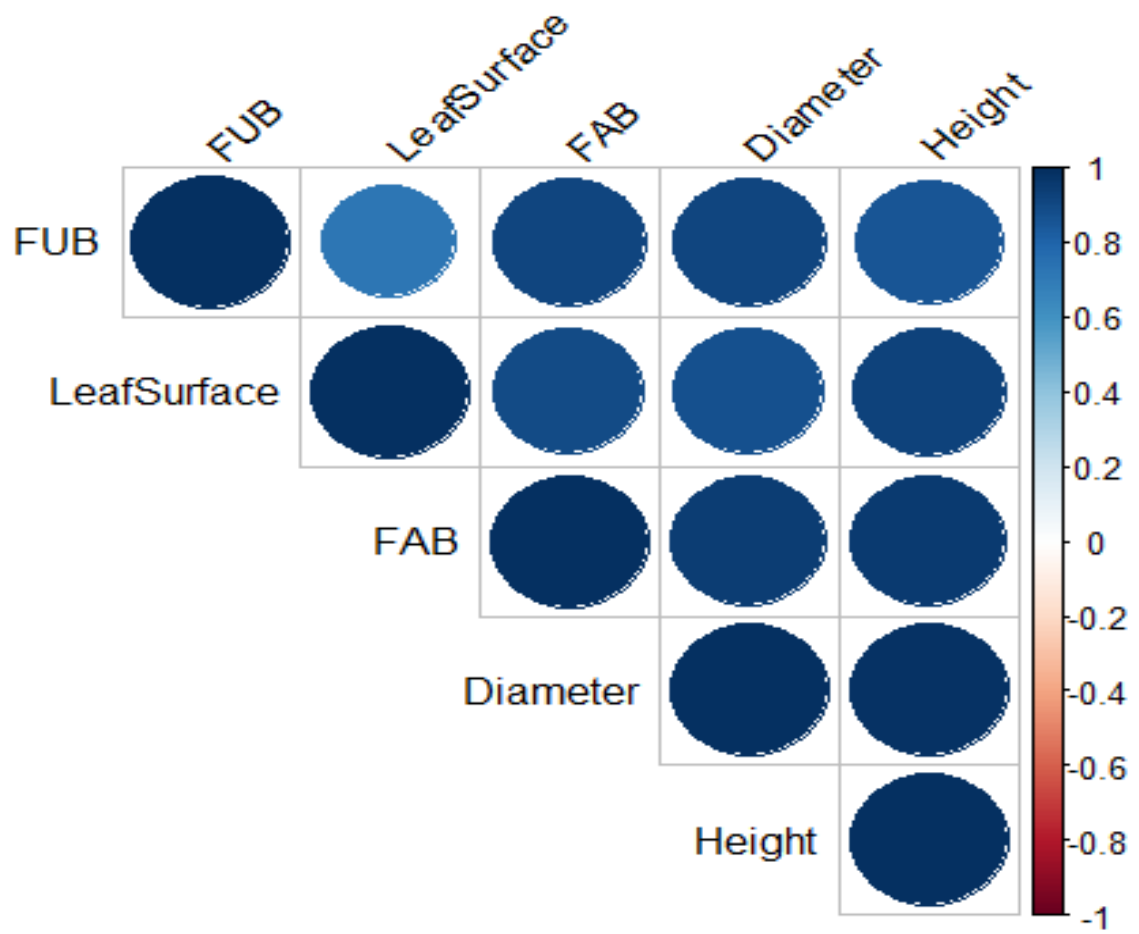

Figure 5. Correlation coefficients of the different parameters. FAB: fresh aerial biomass; FUB: fresh underground biomass.

\section{Discussion}

The deteriorating environmental effects arising from the misuse of pesticides and chemical fertilizers in agriculture has resulted in the pursuit of eco-friendly means of producing agricultural produce without compromising the safety of the environment [40]. These ecological means include the use of PGPR such as P. putida and chitosan, a bioproduct derived from chitin extracted from crustaceans. The knowledge on the tolerant effect of 
P. putida to abiotic stress under in vitro conditions as well as the synergistic effect of this strain in combination with chitosan on maize cultivation under greenhouse conditions was the subject of this study.

\subsection{Effect of Temperature, $p H$, and Salinity on the Growth of P. putida Strain}

A number of abiotic factors, including temperature, salinity, drought, pesticide and fertilizer application, soil $\mathrm{pH}$, and heavy metal contamination, also impede crop productivity [41]. Among these factors, temperature, salinity, and acidity are among the main causes of abiotic stress in plants, causing adverse consequences on the development and quality of harvested products.

The growth of the $P$. putida strain was observed at the different temperatures tested (Figure 1a). It reached its optimum growth at $30^{\circ} \mathrm{C}$ but reduced from $40^{\circ} \mathrm{C}$. At extreme temperatures $\left(4,16,48\right.$, and $\left.50^{\circ} \mathrm{C}\right)$, this strain maintained an appreciable but low growth rate. These results are similar to those of [29] with the Pantoea agglomerans lma2 strain that was positive at the different temperatures tested. Indeed, temperature is one of the most important factors that governs the physiology and growth of microorganisms [42].

For the growth of the strain under different $\mathrm{pH}$ variations, it was noted that $P$. putida grew from $\mathrm{pH} 4$ to $\mathrm{pH} 8$ (Figure $1 \mathrm{~b}$ ). The ability of the strain to grow over a wide range of $\mathrm{pH}$ is indicative of its survival ability. This is in agreement with the work of [43] on Pantoea agglomerans CPA-2, able to grow at $\mathrm{pH} 4.5$ to $\mathrm{pH}$ 8.6. The same is true for the work of [29], which showed that Pantoea agglomerans lma2 grew in a wide range of $\mathrm{pH}$ from $\mathrm{pH} 4$ to $\mathrm{pH}$ 8. The use of PGPR will go a long way in supporting the plant to develop both intrinsic and extrinsic ability to tolerate stressful conditions and sustain yield [11].

Concerning salinity, P. putida was found to be salt tolerant at different concentrations $(0.2 \mathrm{M}$ to $1 \mathrm{M})$ (Figure $1 \mathrm{c})$. It retained a strong growth capacity in the presence of $\mathrm{NaCl}$ at a concentration of 0.2 to $0.4 \mathrm{M}$, but from a NaCl concentration equivalent to $0.8 \mathrm{M}$, the growth of the strains slowed down. Salinity is considered among the abiotic stresses most impacting agriculture for its ability to interfere with crop development and quality. For this reason, practices and innovations that could contain the deleterious effects of such stress are of pivotal importance for maintaining acceptable crop yields [44]. In the last few years, research has shown that the use of salt-tolerant plant growth promoting rhizobacteria (ST-PGPR) in saline agriculture can be harnessed for enhancing productivity and improving soil fertility as well [45]. Authors in [46] also reported that under stress conditions, PGPR can improve the injurious impacts and enhance the yield production under salt conditions.

\subsection{Effects of Combination Chitosan and P. putida on Growth Parameters}

This study shows the positive effect of the combination of chitosan and PGPR on the growth of maize plants. Indeed, inoculation of seeds with chitosan extracted from C. amnicola and C. armatum and their combination with P. putida on day 30 after sowing induced an improvement in growth parameters, which vary from one treatment to another (Table 2). In addition, the results (Figures 3-5) show a significant difference between maize plant heights, crown diameters, and leaf areas depending on the treatments applied.

Regarding growth parameters, such as height, crown diameter, and leaf area of the plants, the highest values were obtained with plants treated with the combination of chitosan extracted from C. armatum and P. putida, which induced increases of $26.8 \%, 31 \%$, and $55.7 \%$, respectively, with respect to the control. This rate of improvement in height is higher than the $17 \%$ obtained by [47] following the inoculation of maize under greenhouse conditions with chitosan extracted from lobsters combined with strains of Azospirillum lipoferum-P. fluorescens-P. putida. Authors in [48] observed a significant increase in crop yield of $30-50 \%$ compared to plants not inoculated with the PGPR strain Azospirillum brasilense (HM053). Various research works have focused mainly on the evaluation of rhizobacteria for their ability to induce improvements in growth and yield parameters in cereals under controlled conditions $[12,47,49]$. Ref. [50] mentioned that the use of microbial 
inoculants is a reliable alternative to the use of chemical inputs because these microbial inoculants can act as biofertilizers, bioherbicides, biopesticides, and biocontrol agents. As for the work of [51], it revealed that the application of chitosan increased the percentage of black pepper height and diameter compared to control. Indeed, chitosan has an excellent film-forming property, facilitates the formation of a semi-permeable film on the seed surface that can maintain seed moisture and absorb soil moisture, and thus can promote seed germination [52]. The work of [27] also showed the positive effects of chitosan extracted from the exoskeletons of $C$. amnicola and C. armatum on in vitro maize seed germination. Several authors have reported the beneficial effects of chitosan application on legume development [52,53]. Authors in [16] reported in their study that the integrated application of PGPR with chitosan significantly reduced symptoms caused by papaya ringspot virusW (PRSV-W) and tomato chlorotic spot virus (TCSV). The improved effect of chitosan and PGPR has already been reported for other plants and has significantly reduced the severity of tomato leaf curl virus (ToLCV) disease [25] and cucumber mosaic virus [54]. Authors in [20] also reported in their study that foliar application of oligochitosans at different concentrations played a positive role on the growth of tomato and eggplant plants. Chitosan is efficient in agriculture by inducing a signal to synthesize plant hormones such as gibberellins and improve growth and development through a signaling pathway related to auxin biosynthesis [55]. The application of chitosan and PGPR as individual treatments or in combination was effective in improving plant growth and suppressing the severity of disease caused by the Squash Mosaic Virus (SqMV) on cucumber plants [56]. Authors in [57] also showed in their research that the application of chitosan could promote plant germination and growth and reduce harmful salinity.

\subsection{Effects of Chitosan and P. putida on Biomass Yield Parameters}

Table 3 shows the average biomass obtained from maize plants per treatment. The results indicate that the effect of the different treatments is very significant on the performance of the maize plants regardless of the type of biomass measured. In fact, an increase of between $18 \%$ and $97 \%$ in the fresh aerial biomass of the treated plants was observed compared to the control plants, whereas an increase of $40.8 \%$ to $111.2 \%$ was observed for the underground biomass. This improvement could be explained by the fact that PGPRs readily colonize the root rhizosphere and establish both free life and intimate associations with host plants [5], which could promote plant growth. The stimulating effect of chitosan, on the other hand, can be attributed to increased availability and absorption of water and essential nutrients by adjusting the osmotic pressure of cells, and reduced accumulation of harmful free radicals by increasing antioxidant and enzyme activities [58]. This effect can also be attributed to an increase in the key enzymatic activities of nitrogen metabolism (nitrate reductase, glutamine synthetase, and protease) and to improved nitrogen $(\mathrm{N})$ transport in functional leaves, as well as to an increase in photosynthesis, which promoted plant growth and development [59]. Ref. [60] reported also that PGPRs can help plants absorb nutrients, control the proliferation of plant pathogens, and can have a positive impact on the natural biodiversity of the soil, thus contributing to plant growth and development. These bacteria also serve as plant growth regulators by producing the phytohormones indole-acetic acid (IAA), 1-aminocyclopropane-1-carboxylic acid (ACC), cytokinins, and gibberellins (GA) [61,62].

Furthermore, ref. [23] reported that foliar-applied chitosan, in particular $200 \mathrm{mg} / \mathrm{L}$, increased common bean plant growth, yield, and its quality, as well as physiological constituents in plant shoot under stressed or non-stressed conditions as compared to chitosan untreated plants of common bean. The application of chitosan to rice grains resulted in a significant increase in yield. This increase was due to the induction of phytoalexin accumulation in plant tissues [63]. Given the importance of chitosan and PGPRs in agriculture, their use could therefore reduce dependence on chemical fertilizers and pesticides in the future. 


\section{Conclusions}

Agricultural practices that reduce or eliminate chemical fertilizers and pesticides through the use of natural products are of paramount importance today for a sustainable and environmentally friendly agriculture. To this end, the application of bioproducts such as PGPR and chitosan in agriculture is one of the promising alternatives to combat abiotic stress in crops and to ensure food and health security of the population. This study revealed through in vitro tests that the strain of PGPR under study, P. putida, showed potentialities of tolerance to abiotic stress such as temperature, $\mathrm{pH}$, and salinity. This study also showed that the application of each of the chitosans extracted from local crabs (C. amnicola and C. armatum) alone or in combination with the rhizobacterium P. putida improved the growth and biomass yield parameters of the maize plants. Plants treated with the combination of chitosan extracted from C. armatum with P. putida induced the best results. This study therefore proves the possibility of using rhizobacteria and chitosan as biostimulants in agricultural production for sustainable and environmentally friendly agriculture in the face of climate change. However, real-world field experiments are needed to better establish the best treatment option for improving maize grain yields.

Author Contributions: N.A.A., T.M., D.D.-N., O.A., and H.L. carried out the experimental work and analysis. N.A.A., T.M., M.Y.A., A.A., O.O.B., and L.B.-M. contributed to the designing, supervision, and interpretation of the results. N.A.A., T.M., L.B.-M., and O.O.B. revised the final draft. O.O.B. reviewed the final project. All authors participated equally in the work and have read and agreed to the published version of the manuscript.

Funding: This study (Projet CNS-Maï-Chitosane 2018) was funded by the Agricultural Productivity Project in West African (WAAPP/PPAAO-Benin).

Data Availability Statement: Main data are contained within the article; further data presented in this study are available on request from the corresponding author.

Acknowledgments: The authors gratefully acknowledge the Agricultural Productivity Project in West African (WAAPP/PPAAO-Benin), the Centre Nationale de Spécialisation sur le maïs (CNS-Maïs) de l'Institut National des Recherches Agricoles du Bénin (INRAB), the Laboratoire de Biologie et de Typage Moléculaire en Microbiologie (LBTMM), and the National Research Foundation, South Africa Grants (UID123634) to O.O.B.; N.A.A. is grateful to North-West University (South Africa) for a postdoctoral fellowship award.

Conflicts of Interest: The authors declare no conflict of interest.

\section{References}

1. Bhat, M.A.; Kumar, V.; Bhat, M.A.; Wani, I.A.; Dar, F.L.; Farooq, I.; Bhatti, F.; Koser, R.; Rahman, S.; Jan, A.T. Mechanistic Insights of the Interaction of Plant Growth-Promoting Rhizobacteria (PGPR) With Plant Roots toward Enhancing Plant Productivity by Alleviating Salinity Stress. Front. Microbiol. 2020, 11, 1952. [CrossRef]

2. Adeleke, B.S.; Babalola, O.O. The endosphere microbial communities, a great promise in agriculture. Int. Microbiol. 2020, $24,1-17$. [CrossRef]

3. Savci, S. An agricultural pollutant: Chemical fertilizer. Int. J. Environ. Sci. Dev. 2012, 3, 11-14. [CrossRef]

4. Godfray, H.C.J.; Beddington, J.R.; Crute, I.R.; Haddad, L.; Lawrence, D.; Muir, J.F.; Pretty, J.; Sherman, R.; Thomas, S.M.; Toulmin, C. Food security: The challenge of feeding 9 billion people. Science 2010, 327, 812-818. [CrossRef]

5. Jochum, M.D.; McWilliams, K.L.; Borrego, E.J.; Kolomiets, M.V.; Niu, G.; Pierson, E.A.; Jo, Y.-K. Bioprospecting plant growthpromoting rhizobacteria that mitigate drought stress in grasses. Front. Microbiol. 2019, 10, 2106. [CrossRef] [PubMed]

6. Lugtenberg, B.; Kamilova, F. Plant-growthpromoting rhizobacteria. Annu. Rev. Microbiol. 2009, 63, 541-556. [CrossRef] [PubMed]

7. Noumavo, A.P.; Agbodjato, A.N.; Gachomo, E.W.; Salami, H.A.; Baba-Moussa, F.; Adjanohoun, A.; Kotchoni, S.O.; Baba-Moussa, L. Metabolic and biofungicidal properties of maize rhizobacteria for growth promotion and plant disease resistance. Afr. J. Biotechnol. 2015, 14, 811-819.

8. Agbodjato, N.A.; Amogou, O.; Noumavo, P.A.; Dagbénonbakin, G.; Salami, H.A.; Karimou, R.; Alladé, A.M.; Baba-Moussa, F.; Adebayo, O.; Adjanohoun, A.; et al. Biofertilising, plant-stimulating and biocontrol potentials of maize plant growth promoting Rhizobacteria isolated in central and northern Benin. Afr. J. Microbiol. Res. 2018, 12, 664-672.

9. Adeoyo, O.R. Plant Growth-Promoting Potentials of Some Indigenous Bacterial Isolates. IOSR-JPBS 2019, 14, 5-10.

10. Ojuederie, O.B.; Olanrewaju, O.S.; Babalola, O.O. Plant Growth Promoting Rhizobacterial Mitigation of Drought Stress in Crop Plants: Implications for Sustainable Agriculture. Agronomy 2019, 9, 712. [CrossRef] 
11. Enebe, M.C.; Babalola, O.O. The influence of plant growth-promoting rhizobacteria in plant tolerance to abiotic stress: A survival strategy. Appl. Microbiol. Biotechnol. 2018, 102, 7821-7835. [CrossRef]

12. Karnwal, A. Isolation and identification of plant growth promoting rhizobacteria from maize (Zea mays L.) rhizosphere and their plant growth promoting effect on rice (Oryza sativa L.). J. Plant Prot. Res. 2017, 57, 144-151. [CrossRef]

13. Dutta, P.K.; Dutta, J.; Tripathi, V.S. Chitin and chitosan: Chemistry, properties and applications. J. Sci. Ind. Res. 2004, 63, $20-31$.

14. Rinaudo, M. Chitin and chitosan: Properties and applications. Prog. Polym. Sci. 2006, 31, 603-632. [CrossRef]

15. Boonlertnirun, S.; Meechoui, S.; Sarobol, E. Physiological and morphological responses of field corn seedlings to chitosan under hypoxic conditions. Sci. Asia 2010, 36, 89-93. [CrossRef]

16. Xing, K.; Zhu, X.; Peng, X.; Qin, S. Chitosan antimicrobial and eliciting properties for pest control in agriculture: A review. Agron. Sustain. Dev. 2015, 35, 569-588. [CrossRef]

17. Doğdu, S.A.; Turan, C.; Depci, T. Extraction and Characterization of Chitin and Chitosan from Invasive Alien Swimming Crab Charybdis longicollis. NESciences 2021, 6, 96-101.

18. Shehata, S.A.; Fawzy, Z.F.; El-Ramady, H.R. Response of cucumber plants to foliar application of chitosan and yeast under greenhouse conditions. Aust. J. Basic. Appl. Sci. 2012, 6, 63-71.

19. Abdel-Mawgoud, A.M.R.; Tantawy, A.S.; El-Nemr, M.A.; Sassine, T.N. Growth and yield response of strawberry plants to chitosan application. Eur. J. Sci. Res. 2010, 39, 170-177.

20. Sultana, S.; Islam, M.; Khatun, M.A.; Hassain, M.A.; Huque, R. Effect of Foliar Application of Oligo-chitosan on Growth, Yield and Quality of Tomato and Eggplant. Asian J. Agric. Res. 2017, 11, 36-42. [CrossRef]

21. Farouk, S.; Mosa, A.A.; Taha, A.A.; Heba, M.I.; ELGahmery, A.M. Protective effect of humic acid and chitosan on radish (Raphanus sativus, L. var. sativus) plants subjected to cadmium stress. J. Stress. Physiol. Biochem. 2011, 7, 99-116.

22. Farouk, S.; Amany, R.A. Improving growth and yield of cowpea by foliar application of chitosan under water stress. Egypt. J. Biol. 2012, 14, 14-26. [CrossRef]

23. Abu-Muriefah, S.S. Effect of chitosan on common bean (Phaseolus vulgaris L.) plants grown under water stress conditions. Int. Res. J. Agric. Sci. Soil Sci. 2013, 3, 192-199.

24. Hidangmayum, A.; Dwivedi, P.; Katiyar, D.; Hemantaranjan, A. Application of chitosan on plant responses with special reference to abiotic stress. Physiol. Mol. Biol. Plants 2019, 25, 313-326. [CrossRef]

25. Mishra, S.; Jagadeesh, K.S.; Krishnaraj, P.U.; Prem, S. Biocontrol of Tomato leaf curl virus (ToLCV) in tomato with chitosan supplemented formulation of Pseudomonas sp. under field conditions. Aust. J. Crop. Sci. 2014, 8, 47-355.

26. Yallou, C.G.; Aïhou, K.; Adjanohoun, A.; Toukourou, M.; Sanni, O.A.; Ali, D. Itinéraires techniques de production de maïs au Bénin. Fiche Tech. Bibliothèque Natl. Du Bénin Dépôt Légal $N^{\circ}$ 2010, 4922, 18.

27. Mikpon, T.; Agbodjato, N.A.; Dah-Nouvlessounon, D.; Amogou, O.; Lehman, H.; N'tcha, C.; Noumavo, P.A.; Assogba, S.; Allagbe, M.; Ahissou, H.; et al. Extraction of chitosan from the exoskeletons of two species of crabs (Callinectes amnicola and Cardisoma armatum) and evaluation of its effectiveness on in vitro germination of maize (Zea mays 1.) in Benin. J. Glob. Biosci. 2020, 9, 8063-8077.

28. Adjanohoun, A.; Baba-Moussa, L.; Glele-Kakaï, R.; Allagbe, M.; Yehouenou, B.; Gotoechan-hodonou, H.; Sikirou, R.; Sessou, P.; Sohounhloue, D. Caractérisation des rhizobactéries potentiellement promotrices de la croissance végétative du maïs dans différents agrosystèmes du Sud-Bénin. Int. J. Biol. Chem. Sci. 2011, 5, 433-444. [CrossRef]

29. Silini-Cherif, H.; Silini, A.; Ghoul, M.; Yadav, S. Isolation and Characterization of Plant Growth Promoting Traits of a Rhizobacteria: Pantoea agglomerans lma2. Pak. J. Biol. Sci. 2012, 15, 267-276. [CrossRef] [PubMed]

30. Oanh, T.; Robert, H.; Fréderic, M.; Patrick, N. Valorisation des résidus industriels de pêches pour la transformation de chitosane par technique hydrothermo-chimique. Revue Sci. l'eau 2007, 20, 253-262.

31. Govindappa, M.; Ravishankar, R.V.; Lokesh, S. Screening of Pseudomonas fluorescens isolates for biological control of Macrophomina phaseolina root-rot of safflower. Afr. J. Agric. Res. 2011, 6, 6256-6266. [CrossRef]

32. Gholami, A.; Shahsavani, S.; Nezarat, S. The effect of Plant Growth Promoting Rhizobacteria (PGPR) on germination, seedling growth and yield of maize. World Acad. Sci. Eng. Technol. Int. J. Agric. Biosyst. Eng. 2009, 3, 9-14.

33. Etèka, A.C. Contribution des 'Jachères' Manioc Dans L'amélioration du Rendement des Cultures et du Prélèvement des Nutriments: Cas de la Succession Culturale Manioc-Maïs au Centre du Benin, Thèse de DEA; Faculté des Sciences Agronomiques, Université d'Abomey Calavi: Calavi, Bénin, 2005; p. 107.

34. Fernández, F.; Gómez, R.; Vanegas, L.F.; Martínez, M.A.; de la Noval, B.M.; Rivera, R. Producto Inoculante Micorrizógeno; Oficina Nacional de Propiedad Industrial: Cuba, Patente, 2000; p. 22641.

35. Walkley, A.; Black, I.A. An examination of the Degtjareff method for determining soil organic matter and a proposed modification of the chromic acid titration method. Soil. Sci. 1934, 37, 29-38. [CrossRef]

36. Bray, R.H.; Kurtz, L.T. Détermination du phosphore organique total et des formes disponibles dans les sols. Soil. Sci. 1945, 59, 39-46. [CrossRef]

37. Thomas, G.W. Exchangeable cations. In Methods of Soil Analysis. Part 2: Chemical and Microbiological Properties, 2nd ed.; Page, A.L., Ed.; Agronomy, American Society of Agronomy, Soil Science Society of America: Madison, DC, USA, 1982; Volume 9, pp. 159-165.

38. Ruget, F.; Bonhomme, R.; Chartier, M. Estimation simple de la surface foliaire de plantes de maïs en croissance. Agronomie 1996, 16, 553-562. [CrossRef] 
39. Douglas, C.E.; Michael, F.A. On distribution-free multiple comparisons in the one-way analysis of variance, Communications in Statistics. Theory Methods 1991, 20, 127-139. [CrossRef]

40. Enagbonma, B.J.; Babalola, O.O. Potentials of termite mound soil bacteria in ecosystem engineering for sustainable agriculture. Ann. Microbiol. 2019, 69, 211-219. [CrossRef]

41. Ahmad, P. Oxidative Damage to Plants: Antioxidant Networks and Signaling; MA Academic Press: San Diego, CA, USA, 2014; pp. 92101-94495.

42. Rahman, M.S.; Mubassara, S.; Hoque, S.; Khan, Z.U. Effect of some environmental factors on the growth of Azospirillum Species isolated from Ssaline soils of Satkhira district, Bangladesh. Bangladesh J. Microbiol. 2006, 23, 145-148. [CrossRef]

43. Costa, E.; Usall, J.; Teixido, N.; Delgado, J.; Vinas, I. Water activity, temperature and pH effects on growth of the biocontrol agent Pantoea agglomerans CPA-2. Can. J. Microbiol. 2020, 48, 1082-1088. [CrossRef]

44. D'Amato, R.; Del Buono, D. Use of a Biostimulant to Mitigate Salt Stress in Maize Plants. Agronomy 2021, 11, 1755. [CrossRef]

45. Grover, M.; Ali, S.Z.; Sandhya, V.; Rasul, A.; Venkateswarlu, B. Role of microorganisms in adaptation of agriculture crops to abiotic stresses. World J. Microbiol. Biotechnol. 2011, 27, 1231-1240. [CrossRef]

46. Abdelaal, K.A.; Tawfik, S.F. Response of Sugar Beet Plant (Beta vulgaris L.) to Mineral Nitrogen Fertilization and Bio-Fertilizers. Int. J. Curr. Microbiol. Appl. Sci. 2015, 4, 677-688.

47. Agbodjato, A.N.; Noumavo, P.A.; Adjanohoun, A.; Agbessi, L.; Baba-Moussa, L. Synergistic Effects of plant growth gromoting rhizobacteria and chitosan on in vitro seeds Germination, Greenhouse growth, and nutrient uptake of Maize (Zea mays L.). Biotech. Res. Int. 2016, 2016, 1-11. [CrossRef]

48. Scott, S.; Housh, A.; Powell, G.; Anstaett, A.; Gerheart, A.; Benoit, M.; Wilder, S.; Schueller, M.; Ferrieri, R. Crop Yield Ferritin, and Fe(II) boosted by Azospirillum brasilense (HM053) in Corn. Agronomy 2020, 10, 394. [CrossRef]

49. Qaisrani, M.M.; Mirza, M.S.; Zaheer, A.; Malik, K.A. Isolation and identification by 16s rRNA sequence analysis of Achromobacter, Azospirillum and Rhodococcus strains from the rhizosphere of maize and screening for the beneficial effect on plant growth. Pak. J. Agric. Sci. 2014, 51, 91-99.

50. Alori, E.T.; Babalola, O.O. Microbial Inoculants for Improving Crop Quality and Human Health in Africa. Front. Microbiol. 2018, 9, 2213. [CrossRef]

51. Uge, E.; Sulandari, S.; Hartono, S.; Somowiyarjo, S. The effect of chitosan application against plant growth and intensity of stunting disease on black pepper (Piper nigrum L.) seedlings. J. Perlindungan Tanam. Indones. 2018, 22, 224-232. [CrossRef]

52. Zeng, D.; Luo, X.; Tu, R. Application of bioactive coatings based on chitosan for soybean seed protection. Int. J. Carbohydr. Chem. 2012, 2012, 1-5. [CrossRef]

53. Costales-Menéndez, D.; Falcón-Rodríguez, A.B. Combinación de formas de aplicación de quitosano en el desarrollo de soja biofertilizada. Cultiv. Trop. 2018, 39, 71-79.

54. Zehnder, G.W.; Murphy, J.F.; Sikora, E.J.; Kloepper, J.W. Application of rhizobacteria for induced resistance. Eur. J. Plant. Pathol. 2001, 107, 39-50. [CrossRef]

55. Uthairatanakij, A.; Teixeira da Silva, J.A.; Obsuwan, K. Chitosan for improving orchid production and quality. Orchid. Sci. Biotech. 2007, 1, 1-5.

56. Firmansyah, D.; Widodo, S.; Hendrastuti. Chitosan and Plant Growth Promoting Rhizobacteria Application to Control Squash mosaic virus on Cucumber Plants. Asian J. Plant. Pathol. 2017, 11, 148-155. [CrossRef]

57. Mahdavi, B. Seed germination and growth responses of Isabgol (Plantago ovata Forsk) to chitosan and salinity. Int. J. Agric. Crop. Sci. 2013, 5, 1084-1088.

58. Guan, Y.J.; Hu, J.; Wang, X.J.; Shao, C.X. Seed priming with chitosan improves maize germination and seedling growth in relation to physiological changes under low temperature stress. J. Zhejiang Univ. Sci. B 2009, 10, 427-433. [CrossRef]

59. Mondal, M.M.A.; Malek, M.A.; Puteh, A.B.; Ismail, M.R.; Ashrafuzzaman, M.; Naher, L. Effect of foliar application of chitosan on growth and yield in okra. Aust. J. Crop. Sci. 2012, 69, 18-921.

60. Igiehon, N.O.; Babalola, O.O. Rhizosphere microbiome modulators: Contributions of nitrogen fixing bacteria towards sustainable agriculture. Int. J. Environ. Res. Public Health 2018, 15, 574. [CrossRef]

61. Khantsi, M.; Adegboye, M.F.; Babalola, O.O. 1-Aminocyclopropane-1-carboxylate deaminase activity as a marker for identifying plant-growth promoting rhizobacteria in cultivated soil. Asia Life. Sci. 2013, 9, 199-211.

62. Ndeddy Aka, R.J.; Babalola, O.O. Effect of bacterial inoculation of strains of Pseudomonas aeruginosa, Alcaligenes feacalis and Bacillus subtilis on germination, growth and heavy metal $(\mathrm{Cd}, \mathrm{Cr}$, and $\mathrm{Ni}$ ) uptake of Brassica juncea. Int. J. Phytoremediation 2016, 18, 200-209. [CrossRef] [PubMed]

63. Lizárraga-Paulín, E.G.; Torres-Pacheco, I.; Moreno-Martínez, E.; Miranda-Castro, S.P. Chitosan application in maize (Zea mays) to counteract the effects of abiotic stress at seedling level. Afri. J. Biotechnol. 2011, 10, 6439-6446. 